\title{
THE EFFECT OF RELATED PARTY TRANSACTIONS ON FIRM PERFORMANCE: THE MODERATING ROLE OF POLITICAL CONNECTION IN INDONESIAN BANKING
}

\author{
SUPATMI $^{1}$, SUTRISNO T. ${ }^{2}$, Erwin SARASWATI ${ }^{3}$, Bambang PURNOMOSIDHI ${ }^{4}$ \\ ${ }^{1,2,3,4}$ Faculty of Economics and Business, Brawijaya University, MT. Haryono Street 165, Malang, 65145, Indonesia \\ E-mails: ${ }^{1}$ patmie@staff.uksw.edu (corresponding author); ${ }^{2}$ sutrisnofeub@yahoo.com; \\ 3erwin_saraswati@yahoo.com; ${ }^{4}$ purnomo@ub.ac.id
}

Received 18 December 2018; accepted 23 January 2019

\begin{abstract}
This study aims to examine the effect of related party transactions (RPTs) on banks' performance and investigates political connections as moderator in their causal relationship. Our sample is 40 Indonesian banks listed on the Indonesian Stock Exchange for the years 2013-2016 with 160 observations as panel data. Based on panel data regression test, our results demonstrate that account receivables-related RPTs have a positive effect on banks' profitability and its market performance (Tobin's Q), but there are consequences of high operating costs and the risk of non-performing loans. Banks receive more funds from their related parties (account payables-related RPTs), banks exhibit higher capital capability and lower market performance. Further, the political connection index in banks significantly affect banks' capability, liquidity, efficiency, and market value through RPTs. This result indicates that political connection strengthens the effects of RPTs on banks' performance. Although this study has limited information in determining political connections and has not considered macroeconomic conditions, these findings imply that political connection plays an important role in banks' performance in Indonesia.
\end{abstract}

Keywords: related party transactions, political connection, firm performance, market performance, banks, Indonesia.

JEL Classification: G21, L25, M41.

\section{Introduction}

Agency problem distorts reported earnings (Watts and Zimmerman 1986) and eventually leads to the discrepancy between accounting-based financial performance and market performance. One of the transactions that potentially imply high agency problem is related party transactions (RPTs). With the ownership structure dominated by family ownership (Claessens et al. 2000, Habib et al. 2017), Indonesian firms are more susceptible to expropriation by majority shareholders on minority shareholders' interests through RPTs (Friedman et al. 2003). Firms from the same group, especially in Asia and more specifically in Indonesia (Utama et al. 2010), even regularly engage in these transactions (Wong et al. 2015). The Indonesian Stock Exchange corporate action data for the years 2012-2016 demonstrates that RPTs or affiliated transactions are the most frequent transactions engaged by the Indonesian listed firms (mean more than 60 percen relative to the total corporate actions).

Studies on the impact of RPTs on firm performance still do not offer conclusive results. According to Gordon et al. (2004) RPTs enables firms to minimize transaction costs with other parties so it is called the efficient transaction hypothesis, or facilitates propping up, i.e., enhancing firm performance (Cheung et al. 2009). Tsai et al. (2015), Utama et al. (2010), and Utama and Utama (2014) empirically support this argument. On the contrary, the adverse effect of RPTs, or the conflict of interest hypothesis, enables majority shareholders to inflict a loss to minority shareholders (Gordon et al. 2004) or to facilitate tunneling, i.e., the expropriation of firm assets for their interests (Cheung et al. 2009). Jian and Wong (2003), Gordon et al. (2004), Cheung et al. (2009), Wahab et al. (2011), and Nekhili and Cherif 
(2011) demonstrate the tendency of firms engaging in RPTs to expropriate minority shareholders' interests and to manage earnings. However, Pozzoli and Venuti (2014), Magdalena and Dananjaya (2015), and Downs et al. (2016) find that RPTs do not affect firm performance.

This research aims to find empirical evidence of the effect of RPTs on the banks performance in Indonesia. This study to confirm the previous studies on the effects of RPTs on firm performance. These previous studies mainly use non-financial firms as their sample. Thus, this study uses the Indonesian banking firms as the sample. We select banks as our sample for the following reasons. Firstly, although in general the banking industry is highly regulated, the majority shareholders of the Indonesian banks (including the government) frequently expropriate, thus indicating the low quality of the banks' corporate governance (Surifah 2013). Secondly, banks play a significant role in the Indonesian economy. Indonesia itself is more a bank-centered economy than a market-centered one.

Further, this study also aims to investigate the role of political connection in moderating the effect of RPTs on banks performance. Fisman (2001) argue that political connection is a valuable resource for many firms, so it can affect firms' transactions or performance. When members of the board of executive directors, members of the board of non-executive directors, or shareholders of a firm are parts of the ruling government or the head of states, their firms will likely enjoy various benefits and facilities in engaging transactions (Faccio 2006). According to the resource dependence theory, political connection provides positive effects for firms, including banks. However, the agency theory argues that political connection is detrimental to banks.

Indonesia has been applying the multi-party system since the collapse of the New Order era. Consequently, firms can maintain their political connection not only by being closely related to presidents or the families of presidents, but also their relationships with politicians from various political parties, including those who hold various positions in parliament, ministries, military service, local governments, together with their close families (Habib et al. 2017). Indonesia as an emerging market, also offers a unique research context for this issue because of its relatively weak investor protection (Leuz and Oberholzer-Gee 2006, Habib et al. 2017) that provides more significant opportunities for expropriation relative to countries with stronger investor protection (Wong et al. 2015).

In addition to adding empirical evidence to agency theory in Indonesia, this study also contributes to providing a different perspective in measuring political connections. According to our knowledge there is still very limited research that measures the level of political connections, especially for Indonesian case. This study will measure political connections in the bank by considering the level of connectivity, and not only the existence or number of politically connected personnel in banks. For regulators, especially the Financial Accounting Standards and the Financial Services Authority, this research can be a consideration in determining banking governance policies, especially in terms of the composition of the company's board.

This research uses 40 Indonesian banks listed on the Indonesian Stock Exchange for the years 2013-2016 with 160 observations as panel data. Based on hypothesis testing using panel data regression, the research hypothesis is supported. However, this study has limited information in tracing political connected personnel in banks and ignoring macroeconomic conditions during the study period.

This paper is organized as follows. The second part presents the theoretical analysis and develops the research hypotheses. Next, the third part discusses research methods used in this study. The fourth part offers and discusses the results. Lastly, the fifth part concludes and presents the research implications and the suggestion for future research.

\section{Theoretical analysis and hypotheses development}

\section{Related party transaction and firm performance}

This research aims to test the effect of RPTs on the Indonesian bank performance and the moderating effect of political connection in this relationship. According to Villalonga and Amit (2006), the agency conflict between principals and agents in Jensen and Meckling (1976) represents the type I agency conflict that is more pervasive in a more dispersed corporate ownership. Meanwhile, in many Asian countries such as Indonesia, the type II agency conflict between majority and minority shareholders is more prevalent. In this context, majority shareholders expropriate minority shareholders through various methods, such as RPTs. Claessens et al. (2000) find that family ownership dominates the ownership structure of Indonesian firms. Weak investor protection and law enforcement enable the majority shareholders of Indonesian firms to exploit RPTs to expropriate the minority shareholders (Habib et al. 2017). RPTs tend to be more conflict of interest than efficient transaction, or be more tunneling type transactions than propping up type.

Many Indonesian firms, including banks, carry out RPTs (Utama et al. 2010). Firms can engage in RPTs that are related to assets, liabilities, sales, or expenses. Assets-related RPTs in banks often take the form of account receivable (credit allocation), while liabilities-related RPTs take the form of clients' saving, either current accounts or savings accounts. Because banks' RPTs are closely related to banks' primary activities, the amount of RPTs affects financial and market performance. Thus, investors likely consider RPTs in their decision making (Jian and Wong 2003).

Sari et al. (2016) demonstrate that relative to firms with dispersed ownership, Indonesian listed firms with 
concentrated ownership tend to engage in tunneling-type transactions. In a similar vein, using Indonesian listed firms as their sample, Utama et al. (2010), Utama and Utama (2014), Tambunan et al. (2017) indicate that RPTs negatively affect firm performance.

Several studies find that both the number and the amount of RPTs negatively affect firm performance, such as Jian and Wong (2003) in China, Gordon et al. (2004) in the US, Lin et al. (2010) in Taiwan, and Wahab et al. (2011) in Malaysia. Thus, RPTs tend to be an expropriati on to minority shareholders. The findings confirm Cheung et al. (2009) who show that in the Chinese context, majority shareholders use RPTs more for the tunneling purpose to expropriate minority shareholders than for propping up. Based on the arguments, we propose the following hypothesis:

$H_{1:}$ Related party transactions negatively affect banks' performance.

\section{Related party transaction, political connection, and firm performance}

This study also predicts that political connection moderates the effect of RPTs on banks performance. The quality of corporate governance, especially the role of the board of directors (BOD), affects the extent of expropriation using RPTs (Pizzo 2013). However, according to Hillman (2005), studies on BOD mainly focus on the composition and characteristics of $\mathrm{BOD}$ and not on the linkage types of $\mathrm{BOD}$, especially the political capital or political connection of the board. Political connection is a firm's valuable resource (Fisman 2001) that affects its performance or transactions. When a firm's executive directors, non-executive directors, or shareholders are parts of governments or heads of states, it is likely that the firm will enjoy various facilities and easiness in their transactions (Faccio 2006).

This study uses two theoretical perspectives in analyzing political connection, i.e. the resource dependence theory and agency theory. Based on the resource dependence theory, the presence of politicians in BOD is a form of corporate political strategy to minimize the external environmental uncertainty of the firm, especially from the government, and eventually to improve firm performance (Hillman 2005). On the other hand, the agency theory argues that politically connected firms are risk takers (Ling et al. 2016), are more likely to experience business failure (Johnson and Milton 2003), and increase the blockholder rent appropriation (Sun et al. 2016). Engaging in RPTs will increase the incentives of BOD to take over (Gordon and Henry 2005) because RPTs potentially inflict a loss for shareholders if firms are better off when engaging non-RPTs than RPTs (Ryngaert and Thomas 2007). Several studies support both theories.

According to Faccio (2006), a firm is politically connected if at least one of its top personnel (CEO, the head of board, president, vice president, or board secretary) or large shareholders (defined as those control at least $10 \%$ of the firm's voting rights) is a head of state (president, king/ queen, or prime minister), a governmental minister, or a parliamentary member. A firm is also politically connected if a relative whose family name is the same as the head of state's or a minister's is in a top management position or a large shareholder. Lastly, a firm is also considered to have a political connection when one of its top executives or large shareholders has a "friendship" relationship with the head of state, ministers, or members of parliament.

Firms directly owned by governments or states exhibit a direct political connection (Adhikari et al. 2006). Ang et al. (2013) and Bona-Sánchez et al. (2014) argue that the presence of ex-politicians in boards also indicates a political connection. Although ex-politicians are not currently involved in politics, they have already accumulated political experience and relationship that are beneficial for their firms. Modifying Faccio (2006) and some previous research to better fit with the Indonesian context, Habib et al. (2017) demonstrate that a firm is politically connected if at least one large shareholder (one who directly or indirectly controls at least $10 \%$ the firm's voting rights) or board member is a current or an ex-member of parliament, a minister or local governmental chief, a senior military officer, or one who is closely related to politicians or a political party. They also extend the relationship with ministers into close relatives (spouses, children, or other family members).

The previous literature shows that politically connected firms can either increase or decrease firm performance. Political connection affects the types and intensity of firms' transactions and eventually affects firm performance, including banks. This study predicts that political connection is more pervasive and plays an increasingly important role for Indonesian firms, especially during the post-New Order era.

Su et al. (2013) find that political connection positively affects firm investment. However, the interaction between political connection and RPTs negatively affects firm investment. These findings indicate that firms' ownership structure plays a significant role in their activities. Liu et al. (2012) demonstrate that political connection in Chinese SOEs facilitates expropriation through RPTs for the interests of the governments and not the firms. Firms often use their political connection to gain special facilities in engaging in transactions, such as RPTs (Habib et al. 2017). Because Indonesia has weak investor protection regulations (Leuz and Oberholzer-Gee 2006, Habib et al. 2017) and many Indonesian firms, including banks, exhibit a "principal-principal conflicts" (Sun et al. 2016), the presence of political connection will moderate the effect of RPTs on banks performance. Based on these arguments, we propose the following hypothesis:

$\mathrm{H}_{2}$ : Political connection moderates the relationship between related party transactions and firm performance. 


\section{Research method}

This study investigates banking firms listed on the Indonesian Stock Exchange for the years of 2013-2016. We select banking firms as our research objects because the banking industry is a highly regulated one and this industry exhibits a considerable amount of expropriation by the controlling shareholders, even including the government that indicates the low quality of its corporate governance (Surifah 2013). Further, the Indonesian economy exhibits a bank-centered characteristic. By using the purposive sampling method, this study generates 160 observation firms for financial performance and 128 observation firms for market performance (information on the stock market price of several banks not be found). We use the secondary data of annual reports and information on the profiles of the sample firms' board of executive directors and board of non-executive directors. We generate our data from $w w w$. $i d x$.co.id and other related websites that contain information on the political connection of the board members.

For the dependent variable (firm/bank perfomance/FP), we use Tobin's $\mathrm{Q}$ (TOBINS) as the proxy of market performance and ROE (return on equity), NPL (non-performing loan), OER (operational efficiency ratio - a ratio between operating expenses and operating revenues), LDR (loan to deposit ratio), and CAR (capital adequacy ratio) as the proxies of financial performance. We use these ratios because they are commonly used to measure the health of banks. For RPTs as our independent variable, we use the RPTs classification of Cheung et al. (2009) that defines tunneling as the ratio between total account receivables and total assets (AR) and propping up as the ratio between total account payables and total liabilities (AP). We then subtract the AR RPT with the AP RPT and divide the difference with total equity to measure the level of RPT.

We measure political connection (PC) as the moderating variable with the political connection score index (PCIDX) as the natural logarithm of the political connection score. We define political connection by adopting Habib et al. (2017). Political connection score is measured by summing the score of a bank's presence of political connection based on the positions and status. In scoring the bank's presence of a political connection, we modify Tao et al. (2017) to better fit with the Indonesian context. Based on the organizational structure of ministries and government institutions in Indonesia, career or position can be divided into seven levels. Therefore a politically connected board will be scored according to the position held in the government agency. The politically connected board is still in position or will be scored between 2 (lowest) to 8 (highest), while board which is a former government official will be scored between 1 (lowest) to 7 (highest). Zero score is given if the bank has no political connection. Appendix A show example of determining the index of political connections and political connection score.
This study includes blockholder ownership, managerial ownership, firm size, and audit firm size as the control variables. We measure blockholder ownership (OWN) as the percentage of share ownership of individual or institution with the largest ownership and managerial ownership (MNJ) as the proportion of share ownership owned by managers to total shares. Firm size (SIZE) is measured by taking the natural logarithm of total assets, and audit firm size (AUD) is measured by developing a dummy variable that is equal to one if the audit firm is a Big four members and zero otherwise.

This research uses panel data which is a combination of cross-section data and time series data so that hypothesis testing using panel data regression, and here is the regression model:

$$
\begin{aligned}
& F P=\alpha+\beta_{1} A R+\beta_{2} A P+\beta_{3} A R P+\beta_{4} P C+ \\
& \beta_{5} A R \times P C+\beta_{6} A P \times P C+\beta_{7} A R P \times P C+ \\
& \beta_{8} O W N+\beta_{9} M N J+\beta_{10} S I Z E+\beta_{11} A U D+\varepsilon
\end{aligned}
$$

We perform sensitivity tests by measuring political connection in (1) the number of politically connected senior personnel (PCTOT), and (2) the dummy variable (PCDUM) that is equal to one if a bank has a political connection and zero otherwise.

\section{Results and discussion}

Table 1 indicates that during the years 2013-2016 the Indonesian banks engaged more account payables-related RPTs than the account receivables-related RPTs. This finding suggests that the Indonesian banks involved in RPTs more for propping up than for tunneling. Further, the result is in contrast with the Chinese evidence (Cheung et al. 2009). These results are in line with the data that demonstrate that our sample on average exhibit good performance, as indicated by the positive ROE and Tobin's $\mathrm{Q}$ of more than one. These findings also imply that banks utilize their capital effectively and investors value these banks higher than their book values. Meanwhile, according to other performance indicators (NPL, OER, LDR, and CAR), our sample banks qualify as healthy banks according to the Bank of Indonesia’s regulation.

In general, the Indonesian banks tend to be politically connected and to use Big 4 audit firms. The mean value of the largest share ownership (blockholder) is $56.6 \%$, while the average managerial ownership is relatively low (3.12\%). Most banks even do not exhibit any managerial ownership. From 110 firm-year observations, the most prevalent form of political connection is the governmental ownership, followed by the political connection of banks' senior personnel with political parties, military, and ex-ministers. The average political connection score is 7.1, and the average political connection score index is 1.4. Meanwhile, on average the 
Table 1. Descriptive statistics

\begin{tabular}{|c|c|c|c|c|}
\hline $\begin{array}{c}\text { Research } \\
\text { Variables }\end{array}$ & Min & Max & Mean & Std.Dev. \\
\hline AR & 0.000 & 0.139 & 0.016 & 0.029 \\
\hline AP & 0.001 & 0.886 & 0.079 & 0.118 \\
\hline ARP & $(4.289)$ & 0.279 & $(0.364)$ & 0.712 \\
\hline ROE & $(1.066)$ & 0.394 & 0.078 & 0.065 \\
\hline NPL & 0.000 & 8.900 & 2.066 & 1.508 \\
\hline OER & 7.120 & 235.200 & 86.527 & 22.1394 \\
\hline LDR & 5.150 & 140.720 & 84.210 & 15.620 \\
\hline CAR & 8.020 & 87.490 & 19.977 & 8.154 \\
\hline SIZE & 27.474 & 34.576 & 30.894 & 1.817 \\
\hline OWN & 12.460 & 96.920 & 56.600 & 20.667 \\
\hline MNJ & 0.000 & 72.070 & 3.108 & 11.474 \\
\hline TOBINS & 0.014 & 4.227 & 1.374 & 0.911 \\
\hline PCIDX & 0.000 & 3.332 & 1.441 & 1.170 \\
\hline PCTOT & 0.000 & 6.000 & 1.513 & 1.542 \\
\hline
\end{tabular}

\begin{tabular}{|c|c|c|c|}
\hline \multicolumn{2}{|c|}{ Research Variable } & $\mathrm{N}$ & Percentage \\
\hline AUDITOR & Big 4 & 100 & $62.5 \%$ \\
\hline & Non big 4 & 60 & $37.5 \%$ \\
\hline PCDUM & Exist & 110 & $68.8 \%$ \\
\hline & Not Exist & 50 & $31.3 \%$ \\
\hline
\end{tabular}

Variable definitions:

AR: account receivables-related RPTs divided by total assets; AP: account payables-related RPTs divided by total liabilities; ARP: the difference between AR and AP divided by total equity; ROE: return on equity; NPL: non-performing loans; OER: operational efficiency ratio (operating expenses divided by operating revenues); LDR: loan to deposit ratio; CAR: capital adequacy ratio; SIZE: firm size; AUD: audit firm size (dummy variable); OWN: the largest shareholder's ownership; MJN: managerial ownership; PCIDX: political connection score index; PCTOT: the number of politically connected senior personnel in a firm; PCDUM: a dummy variable indicating whether a firm is politically connected (score one) and zero otherwise.

Indonesian banks have 1-2 politically connected senior personnel. These figures suggest that banks' politically connected senior personnel hold very high positions as suggested by the average political connection score of 7.1 although on average banks only have 1-2 politically connected senior personnel.

Further, Table 2 below displays the simple relationship between the existence of political connection in the Indonesian banks, RPT, and bank performance.

Table 2 demonstrates the relationship between the political connection with various indicators of bank performance. Politically connected banks exhibit better ROE, OER, LDR, and Tobin's $\mathrm{Q}$ than non-politically connected banks. These findings indicate that political connection is associated with higher profitability, operating cost efficiency, liquidity, and market value. However, non-politically connected firms exhibit better NPL and CAR than politically connected firms.
Table 2. The mean value of banks' performance, RPT, and political connection

\begin{tabular}{|c|c|c|c|c|c|c|}
\hline $\begin{array}{c}\text { Average } \\
\text { Perfor- } \\
\text { mance } \\
(\%)\end{array}$ & ROE & NPL & OER & LDR & CAR & TOBIN'S Q \\
\hline PC & 0.069 & 2.176 & 83.644 & 85.098 & 19.406 & 1.445 \\
\hline No PC & 0.045 & 1.824 & 92.871 & 82.256 & 21.235 & 1.209 \\
\hline
\end{tabular}

\begin{tabular}{|c|c|c|c|}
\hline Average RPT (\%) & AR & AP & ARP \\
\hline PC & 0.018 & 0.080 & $(0.406)$ \\
\hline No PC & 0.012 & 0.079 & $(0.270)$ \\
\hline
\end{tabular}

Variable definitions see Table 1.

Further, politically connected firms have higher non-performing loans and lower capital adequacy than non-politically connected banks. Finally, the difference between account receivables-related RPTs and account payables-related RPTs is higher for politically connected banks than non-politically connected banks. These findings support Habib et al. (2017) who show that political connection leads firms to engage in more RPTs.

Table 3 demonstrates the results of the Pearson Correlation test for all research variables. The table indicates the positive correlation between account receivables-related RPTs with ROE and the political connection score index and the positive correlation between account-payables RPTs with CAR and the political connection score index. Further, Tobin's $Q$ is positively correlated with the number of politically connected personnel in firms.

This research uses pool data which is a combination of cross-section data and time series data so that hypothesis testing using panel data regression with EViews program. The result of the parameter estimation test finds the hypothesis test using the random effect model (generalized least squares). Table 4 summarizes the hypothesis tests using panel data regression.

Table 4 shows that account receivables-related RPTs positively affect ROE but the difference between account receivables-related RPTs and account payables-related RPsT (ARP) negatively affects ROE. The finding implies that higher credit distribution is associated with higher profitability but higher fund receipts will be countered it. The panel shows that account receivables-related RPTs (AR) negatively affect NPL and OER. It implies that there are consequences of high operating costs and the risk of non-performing loans on credit distribution granted to the related parties.

Different results are found on Tobin's Q where account receivables-related RPTs (AR) positively affect Tobin's $\mathrm{Q}$, but account payables-related RPTs (AP) and the difference between account receivables-related RPT and account payables-related RPT (ARP) negatively affect this performance. These results suggest that more credit allocation to 
Table 3. The Results of the Correlation Test

\begin{tabular}{|c|c|c|c|c|c|c|c|c|c|c|c|c|c|c|c|c|c|}
\hline & & $\frac{\pi}{4}$ & 学 & 娄 & 岀 & 宗 & 夜 & $\bar{z}$ & 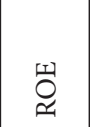 & 弇 & 獣 & 舀 & ¿্ট & 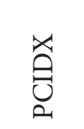 & 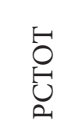 & 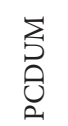 & $\begin{array}{l}\text { 允 } \\
\text { 号 }\end{array}$ \\
\hline \multirow[b]{2}{*}{ 爱 } & \begin{tabular}{|l} 
Pearson \\
Correlation
\end{tabular} & 1 & & & & & & & & & & & & & & & \\
\hline & Sig. (2-tailed) & & & & & & & & & & & & & & & & \\
\hline \multirow[b]{2}{*}{ 安 } & $\begin{array}{l}\text { Pearson } \\
\text { Correlation }\end{array}$ & $.207^{* *}$ & 1 & & & & & & & & & & & & & & \\
\hline & Sig. (2-tailed) & .009 & & & & & & & & & & & & & & & \\
\hline \multirow{2}{*}{ 变 } & $\begin{array}{l}\text { Pearson } \\
\text { Correlation }\end{array}$ & $.473^{* *}$ & -.037 & 1 & & & & & & & & & & & & & \\
\hline & Sig. (2-tailed) & .000 & .643 & & & & & & & & & & & & & & \\
\hline \multirow{2}{*}{ 嵌 } & $\begin{array}{l}\text { Pearson } \\
\text { Correlation }\end{array}$ & $.257^{* *}$ & .022 & .028 & 1 & & & & & & & & & & & & \\
\hline & Sig. (2-tailed) & .001 & .786 & .722 & & & & & & & & & & & & & \\
\hline \multirow{2}{*}{ 虽 } & $\begin{array}{l}\text { Pearson } \\
\text { Correlation }\end{array}$ & .095 & .040 & .073 & $.599^{* *}$ & 1 & & & & & & & & & & & \\
\hline & Sig. (2-tailed) & .230 & .619 & .358 & .000 & & & & & & & & & & & & \\
\hline \multirow{2}{*}{ 㝊 } & \begin{tabular}{|l} 
Pearson \\
Correlation \\
\end{tabular} & .102 & .044 & .143 & .055 & .054 & 1 & & & & & & & & & & \\
\hline & Sig. (2-tailed) & .198 & .577 & .072 & .486 & .494 & & & & & & & & & & & \\
\hline \multirow{2}{*}{$\bar{z}$} & $\begin{array}{l}\text { Pearson } \\
\text { Correlation }\end{array}$ & -.049 & -.125 & .012 & $-.277^{* *}$ & $-.267^{* *}$ & .015 & 1 & & & & & & & & & \\
\hline & Sig. (2-tailed) & .536 & .115 & .881 & .000 & .001 & .847 & & & & & & & & & & \\
\hline \multirow{2}{*}{ 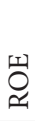 } & $\begin{array}{l}\text { Pearson } \\
\text { Correlation }\end{array}$ & $.323^{* *}$ & .005 & .081 & $.483^{* *}$ & $.160^{*}$ & .101 & -.109 & 1 & & & & & & & & \\
\hline & Sig. (2-tailed) & .000 & .945 & .306 & .000 & .044 & .204 & .169 & & & & & & & & & \\
\hline \multirow{2}{*}{ 完 } & \begin{tabular}{|l} 
Pearson \\
Correlation
\end{tabular} & -.029 & -.021 & -.032 & -.012 & -.098 & .155 & $-.161^{*}$ & $-.167^{*}$ & 1 & & & & & & & \\
\hline & Sig. (2-tailed) & .713 & .792 & .685 & .883 & .219 & .051 & .041 & .035 & & & & & & & & \\
\hline \multirow{2}{*}{ 獣 } & $\begin{array}{l}\text { Pearson } \\
\text { Correlation }\end{array}$ & -.127 & -.051 & -.057 & $-.357^{* *}$ & $-.251^{* *}$ & .024 & .065 & $-.480^{* *}$ & $.350^{* *}$ & 1 & & & & & & \\
\hline & Sig. (2-tailed) & .109 & .525 & .471 & .000 & .001 & .764 & .416 & .000 & .000 & & & & & & & \\
\hline \multirow{2}{*}{ 先 } & \begin{tabular}{|l|l} 
Pearson \\
Correlation \\
\end{tabular} & .038 & .029 & .031 & $.210^{* *}$ & $.343^{* *}$ & $.259^{* *}$ & $-.500^{* *}$ & .081 & .111 & -.152 & 1 & & & & & \\
\hline & Sig. (2-tailed) & .633 & .716 & .695 & .008 & .000 & .001 & .000 & .307 & .163 & .055 & & & & & & \\
\hline \multirow{2}{*}{ 选 } & $\begin{array}{l}\text { Pearson } \\
\text { Correlation }\end{array}$ & -.012 & $.203^{*}$ & -.035 & $-.281^{* *}$ & $-.238^{* *}$ & $-.157^{*}$ & .036 & $-.195^{*}$ & $-.245^{* *}$ & .005 & $-.180^{*}$ & 1 & & & & \\
\hline & Sig. (2-tailed) & .878 & .010 & .657 & .000 & .002 & .047 & .650 & .013 & .002 & .945 & .023 & & & & & \\
\hline \multirow{2}{*}{ 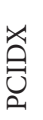 } & $\begin{array}{l}\text { Pearson } \\
\text { Correlation } \\
\end{array}$ & $.246^{* *}$ & $.156^{*}$ & .142 & $.566^{* *}$ & $.281^{* *}$ & -.138 & $-.247^{* *}$ & $.320^{* *}$ & .119 & $-.179^{*}$ & .053 & -.037 & 1 & & & \\
\hline & Sig. (2-tailed) & .002 & .049 & .073 & .000 & .000 & .083 & .002 & .000 & .135 & .024 & .506 & .643 & & & & \\
\hline \multirow{2}{*}{ 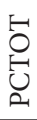 } & $\begin{array}{l}\text { Pearson } \\
\text { Correlation }\end{array}$ & .006 & .056 & .050 & $.382^{* *}$ & .099 & $-.156^{*}$ & $-.196^{*}$ & $.258^{* *}$ & .035 & $-.183^{*}$ & -.060 & .137 & $.804^{* *}$ & 1 & & \\
\hline & Sig. (2-tailed) & .935 & .481 & .528 & .000 & .214 & .049 & .013 & .001 & .660 & .021 & .450 & .084 & .000 & & & \\
\hline \multirow{2}{*}{ 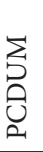 } & $\begin{array}{l}\text { Pearson } \\
\text { Correlation }\end{array}$ & .095 & -.007 & .074 & $.491^{* *}$ & $.313^{* *}$ & $-.244^{* *}$ & $-.256^{* *}$ & $.227^{* *}$ & .108 & $-.194^{*}$ & .085 & -.104 & $.833^{* *}$ & $.663^{* *}$ & 1 & \\
\hline & Sig. (2-tailed) & .230 & .925 & .353 & .000 & .000 & .002 & .001 & .004 & .173 & .014 & .288 & .189 & .000 & .000 & & \\
\hline \multirow{2}{*}{$\begin{array}{l}\mathscr{Z} \\
\text { 范 } \\
0\end{array}$} & \begin{tabular}{|l} 
Pearson \\
Correlation
\end{tabular} & .129 & -.022 & .002 & -.008 & -.133 & .014 & .001 & $.340^{* *}$ & -.138 & -.097 & .010 & $.167^{*}$ & .158 & $.332^{* *}$ & .119 & 1 \\
\hline & Sig. (2-tailed) & .113 & .785 & .985 & .918 & .103 & .862 & .987 & .000 & .091 & .237 & .904 & .040 & .053 & .000 & .146 & \\
\hline
\end{tabular}

a. ${ }^{*}, * * * *$ : significance level at 10,5 , and $1 \%$, respectively.

b. Variable definitions see Table 1 . 
Table 4 . The results of the hypothesis testing

\begin{tabular}{|c|c|c|c|c|c|c|}
\hline Research Variables & ROE & NPL & OER & LDR & CAR & TOBINS'Q \\
\hline Constant & -0.824 & 5.591 & $237.992^{* * *}$ & $99.019^{* * *}$ & $57.408^{\star \star \star}$ & -0.126 \\
\hline $\mathrm{AR}$ & $1.954^{\star *}$ & $-18.506^{\star}$ & $-406.359^{* *}$ & -61.384 & -20.071 & $29.379^{\star * *}$ \\
\hline $\mathrm{AP}$ & -0.032 & -0.914 & -18.841 & -1.264 & 8.518 & $-14.131^{\star * *}$ \\
\hline $\mathrm{ARP}$ & -0.066 & 0.095 & $17.423^{*}$ & -6.286 & 4.389 & $-2.608^{* * *}$ \\
\hline PCIDX & -0.012 & 0.248 & -2.676 & 0.535 & -0.622 & 0.148 \\
\hline SIZE & $0.029^{\star * *}$ & -0.137 & -4.631 & -0.844 & $-1.091^{\star}$ & 0.046 \\
\hline AUD & 0.011 & -0.103 & -2.242 & 5.097 & -1.021 & -0.416 \\
\hline OWN & -0.001 & 0.012 & 0.044 & $0.159^{\star \star}$ & -0.052 & 0.0001 \\
\hline $\mathrm{MNJ}$ & 0.001 & -0.020 & -0.162 & $-0.628^{\star * \star}$ & -0.028 & 0.004 \\
\hline $\mathrm{AR}^{\star P C D I X}$ & -0.539 & 6.738 & $152.883^{* *}$ & 60.519 & -4.374 & $-12.209^{* * *}$ \\
\hline $\mathrm{AP}^{* \mathrm{PCIDX}}$ & 0.092 & -1.254 & -1.568 & $-28.701^{* * *}$ & $16.899^{\star * *}$ & $6.221^{* * *}$ \\
\hline ARP*PCIDX & 0.028 & -0.280 & $-7.209^{*}$ & -1.641 & 0.160 & $1.106^{* * *}$ \\
\hline Adj $R^{2}$ & 0.029 & 0.011 & 0.059 & 0.201 & 0.113 & 0.054 \\
\hline F & 1.446 & 1.147 & $1.900^{\star *}$ & $4.633^{* * *}$ & $2.832^{* * *}$ & $1.663^{\star}$ \\
\hline
\end{tabular}

${ }^{*},{ }^{* *},{ }^{* *}$ : significance level at 10,5 , and $1 \%$, respectively.

Variable definitions see Table 1 .

related parties is associated with higher market performance. However, when banks receive more funds from their related parties, or when the difference between the fund distribution to and the fund receipts from related parties is higher, banks exhibit lower market performance. The result supports first hypothesis for account payables-related RPTs but not for account receivables-related RPTs.

The above findings demonstrate a clear relationship between account payables and receivables, interest expense and revenue, and their impacts on firm profitability, the risk of non-performing loans, operating expense, and market performance. Higher account receivables-related RPTs are associated with higher interest revenue, implying higher net earnings, and market performance. However, when banks engage in more account payables-related RPTs the bank's capability increases but they incur more interest expense that eventually causes the risk of non-performing loans, net earnings, and market performance to decline.

These findings indicate that RPTs do not have different effects as the non-RPTs do. It is less likely that majority shareholders expropriate minority shareholders' wealth. Our results are different from Jian and Wong (2003) and Cheung et al. (2009) for the Chinese case, and Gordon et al. (2004) in the US which show that majority shareholder exploit RPTs to expropriate minority shareholders that eventually harms firm performance. We explain this difference by pointing to the countries' different economic characteristics where Indonesia is more bank-centered while these other countries are more capital market-centered.

Besides, the different categories of related parties may explain why our results differ from other studies. The data suggest that the account-receivables RPTs of the Indonesian bank are mostly corporate credits and not the personal ones. In a similar vein, the account payables-related RPTs of the Indonesian banks are mostly institutional savings. Different from individuals-related RPTs such as RPTs with executive and non-executive directors, institutions-related RPTs are less likely to cause banks to treat the transactions differently. Most banks in our sample disclose that they treat their account receivables-related RPTs and account-payables RPTs similarly to non-RPTs, especially regarding the interest rate. Account receivables-related RPTs increase banks' earnings and market performance, thus indicating that the related institutions utilize credits granted to them for good business purposes.

Further, account receivables-related RPTs that mostly take the form of credit allocation to related parties is considered productive. In 2014-2016, Indonesia was under the Joko Widodo administration that focus on the infrastructure development. This program requires a huge amount of funds; leading banks, especially the state-owned ones, to financially support this program. These findings support the efficient transaction hypothesis for the account receivables-related RPTs and the conflict of interest hypothesis for the account payables' related RPTs (Gordon et al. 2004). However, the results contradict Cheung et al. (2009) who demonstrate that Indonesian banks enjoy the benefits of account receivablesrelated RPTs (propping up) while account payables-related RPTs are a tunneling type.

Table 4 also suggests that the political connection index moderates the effect of account receivables-related RPTs (AR $\left.{ }^{\star} \mathrm{PCIDX}\right)$ on bank performance as measured by OER and Tobins' $\mathrm{Q}$. The results imply that the political connection index moderates the effects of RPTs on banks' operating 
expense efficiency and bank's market performance. The interaction between political connection and account receivables-related RPTs positively affects OER but negatively affets
Tobins' Q. It means that more banks are conducting account receivables-related RPTs and more have political connections, the higher the banks' operating expense efficiency and

Table 5. The results of sensitivity tests

Panel A: Political connection measured with PCTOT

\begin{tabular}{|c|c|c|c|c|c|c|}
\hline Research Variables & ROE & NPL & OER & LDR & CAR & TOBINS'Q \\
\hline Constant & $-0.592^{*}$ & 3.914 & $198.387^{* * *}$ & $97.293^{* * *}$ & $58.514^{\star * \star}$ & 0.565 \\
\hline $\mathrm{AR}$ & $1.869^{\star}$ & $-20.458^{\star}$ & $-376.133^{\star *}$ & -56.227 & -13.051 & $19.485^{\star * *}$ \\
\hline $\mathrm{AP}$ & -0.025 & -0.929 & -22.671 & -3.573 & 10.312 & -6.269 \\
\hline ARP & $-0.101^{\star}$ & -0.253 & 10.783 & -7.667 & $8.420^{\star * *}$ & $-1.211^{\star * *}$ \\
\hline PCTOT & 0.010 & 0.081 & $-4.228^{\star *}$ & 0.265 & -0.419 & 0.099 \\
\hline SIZE & $0.020^{*}$ & -0.075 & $-3.317^{\star}$ & -0.740 & $-1.175^{\star \star}$ & 0.024 \\
\hline AUD & 0.010 & 0.010 & -2.611 & 4.636 & -0.358 & -0.343 \\
\hline OWN & -0.001 & -0.0978 & 0.052 & $0.139^{\star *}$ & -0.032 & 0.001 \\
\hline $\mathrm{MNJ}$ & 0.001 & -0.019 & -0.137 & $-0.629^{* * *}$ & -0.026 & 0.003 \\
\hline $\mathrm{AR}^{\star} \mathrm{PCTOT}$ & -0.619 & 10.331 & $176.015^{\star \star}$ & 58.436 & 2.916 & $-9.121^{* * *}$ \\
\hline $\mathrm{A}^{\star P P C T O T}$ & 0.049 & -0.798 & 4.801 & $-15.254^{\star \star}$ & $6.569^{*}$ & $2.706^{\star * *}$ \\
\hline ARP*PCTOT & $0.048^{*}$ & $-0.108^{\star}$ & -5.165 & 0.854 & $-3.505^{\star * *}$ & $0.528^{* * *}$ \\
\hline Adj $R^{2}$ & 0.033 & 0.002 & 0.055 & 0.197 & 0.169 & 0.020 \\
\hline $\mathrm{F}$ & 1.486 & 0.906 & $1.843^{\star}$ & $4.557^{\star \star \star}$ & $3.950^{\star * *}$ & 1.237 \\
\hline
\end{tabular}

Panel B: Political connection measured with PCDUM

\begin{tabular}{|c|c|c|c|c|c|c|}
\hline \multicolumn{7}{|c|}{ PCDUM (1) } \\
\hline \multirow{2}{*}{ Research Variables } & ROE & NPL & OER & LDR & CAR & TOBINS \\
\hline & $(\mathrm{N}=150)$ & $(\mathrm{N}=150)$ & $(\mathrm{N}=150)$ & $(\mathrm{N}=150)$ & $(\mathrm{N}=150)$ & $(\mathrm{N}=96)$ \\
\hline Constant & $-0.850^{*}$ & 6.255 & $229.324^{\star * *}$ & $100.862^{* *}$ & $44.678^{\star \star}$ & 2.897 \\
\hline $\mathrm{AR}$ & 0.504 & -3.614 & -27.191 & $122.275^{\star *}$ & -49.000 & -1.019 \\
\hline $\mathrm{AP}$ & 0.179 & -0.474 & 14.816 & $-105.747^{\star \star \star}$ & $61.951^{* * *}$ & 0.729 \\
\hline ARP & -0.001 & -0.182 & 5.729 & $-14.411^{\star * *}$ & $5.967^{\star \star}$ & 0.018 \\
\hline SIZE & $0.028^{\star}$ & -0.149 & $-4.616^{\star *}$ & -0.760 & -0.722 & -0.039 \\
\hline AUD & 0.019 & 0.391 & 4.328 & 4.478 & -1.630 & -0.436 \\
\hline OWN & -0.000 & 0.008 & -0.0197 & 0.134 & -0.047 & 0.002 \\
\hline MNJ & 0.009 & -0.050 & -0.355 & $-1.560^{*}$ & -0.446 & 0.007 \\
\hline
\end{tabular}

\begin{tabular}{|c|c|c|c|c|c|c|}
\hline \multicolumn{7}{|c|}{ PCDUM (0) } \\
\hline \multirow{2}{*}{ Research Variables } & ROE & NPL & OER & LDR & CAR & TOBINS \\
\hline & $(\mathrm{N}=50)$ & $(\mathrm{N}=50)$ & $(\mathrm{N}=50)$ & $(\mathrm{N}=50)$ & $(\mathrm{N}=50)$ & $(\mathrm{N}=32)$ \\
\hline Constant & -0.295 & -2.800 & $189.356^{\star *}$ & $107.275^{\star}$ & 66.494 & 2.751 \\
\hline $\mathrm{AR}$ & 0.822 & -10.944 & -158.592 & -87.531 & -43.031 & $22.349^{*}$ \\
\hline $\mathrm{AP}$ & -0.062 & -0.765 & -19.551 & 4.162 & 7.646 & 0.234 \\
\hline ARP & -0.017 & 0.181 & 1.358 & 2.579 & 4.303 & -0.284 \\
\hline SIZE & 0.012 & 0.176 & -3.511 & -1.104 & -1.015 & -0.057 \\
\hline AUD & 0.012 & $-1.275^{\star}$ & -9.519 & 4.363 & -2.126 & -0.170 \\
\hline OWN & -0.001 & 0.005 & 0.252 & 0.193 & $-0.203^{\star}$ & -0.001 \\
\hline $\mathrm{MNJ}$ & 0.000 & -0.021 & -0.149 & $-0.643^{\star * *}$ & -0.027 & -0.008 \\
\hline
\end{tabular}

a. ${ }^{*},{ }^{* *},{ }^{* *}$ : significance level at 10,5 , and $1 \%$, respectively.

b. Variable definitions see Table 1 . 
the lower its market performance. The political connection index also moderates the effect account payables-related RPTs (AP*PCIDX) on the bank's liquidity, capability, and market performance. The interaction between political connection and account payables-related RPTs positively affects CAR and Tobins' $Q$ but negatively affets LDR. It means that more banks are conducting account payables-related RPTs and more have political connections, the higher the banks' capability and market performance but the lower its liquidity. The political connection index is a pure moderator of the impact of RPTs on LDR and CAR. Meanwhile, the research results also proved that the effect for all types of RPTs on market performance (Tobin's $\mathrm{Q}$ ) is moderated by the political connection index. It suggests that investors' perception of the existence of personal connected politics in the company into consideration of investors in seeing the effect of RPTs on bank performance.

In general, this study indicates that political connection strengthens the effects of RPTs on banks' capability, profitability, non-performing loans, liquidity, efficiency, and market value, so the second hypothesis is supported. The adjusted $\mathrm{R}^{2}$ value shows an increase after the political connection variable is inserted as a moderation variable in the test than if it is not included in the test (output test is not presented here). These results support with Habib et al. (2017) who find that the interaction between political connection and RPTs positively affects earnings management practice among Indonesian non-financial firms. Although different research samples, the results of this study both support that political connections within the company in Indonesia play an important role in the company, including bank, especially if associated with RPTs.

Table 5 summarizes the hypothesis tests using panel data regression for the number of politically connected senior personnel in a bank (PCTOT) and political connection in dummy variable (PCDUM).

We find that there are several different findings by comparing Table 5 Panel A and Table 3. Table 5 Panel A shows that account payables-related RPTs (AP) has no effect on market performance and the number of politically connected personnel moderates ARP on banks' capital capability. This is different from the findings in Table 3 that account payablesrelated RPTs (AP) negatively affects market performance and the political connection index actually moderates the account payables-related RPTs (AP) of banks' capability, but not the RPTs level or ARP (the difference between account receivables-related RPTs and account payables-related RPTs).

The findings demonstrate that the number of banks' politically connected senior personnel moderates the effects of RPTs on banks' non-performing loans, capability, liquidity, and market value. More specifically, the number of banks' politically connected senior personnel is a quasi-moderator of the effect of RPTs on ROE, OER, CAR, and Tobin's Q
(AR*PCTOT dan $\mathrm{ARP} * \mathrm{PCTOT})$ but a pure moderator of the effect of RPTs on NPL, LDR, and Tobin's Q (AP*PCTOT). It implies that the personal number of banks' politically connected senior personnel moderates the effect of RPTs to bank performances, both accounting and market performance.

Panel B Table 5 suggests that political connection moderates the effect of all RPTs (AR, AP, and ARP) on LDR. There are the RPTs effect on bank liquidity with political connections and no effect on banks without political connections. Connected banks do more account receivablerelated RPTs (AR) the higher its liquidity but when they do more of account payable-related RPTs (AP) and the difference between account receivables-related and account payables-related RPTs (ARP) the lower the bank liquidity. Panel B Table 5 also demonstrates that political connection moderates the effect of account payable-related RPTs (AP) and the difference between account receivables-related and account payables-related RPTs (ARP) on Tobin's Q. There are positively effect of account payable-related RPTs (AP) and the difference between account receivables-related and account payables-related RPTs (ARP) on Tobin's Q in connected banks. Further, connected banks that received more funds from related parties have higher market performance. It implies that there is a difference of RPTs effect on bank performance between the connected banks and non-connected banks in politics. This finding is different from the findings in the previous table.

The explanation above shows that measuring different political connections will provide different results of analysis. It proves that the use of a political connection index that measures the level of political connections is able to provide a better explanation of the impact of political connections in the causal relationship of RPTs to firm performance.

\section{Conclusions}

This study aims to investigate the effect of RPTs on firm performance and the moderating effect of political connection on this relationship in the context of Indonesian banking. This research finds that RPTs effect the liquidity and market performance of the bank with a political connection. The account receivables-related RPTs (credit distribution granted to the related parties) will increase banks profitability and its market performance, but there are consequences of high operating costs and the risk of non-performing loans. Meanwhile, banks receive more funds from their related parties (account payables-related RPTs), banks exhibit higher capability and lower market performance. Its finding supports first hypothesis for account payables-related RPTs but not for account receivables-related RPTs. This research also suggests that the political connection index moderates the effect of RPTs on bank performance. The results imply that the political connection index moderates the effects 
of RPTs on operating expense efficiency, liquidity, capability, and market performance of the bank, so the second hypothesis is supported. In general, this study indicates that political connection strengthens the effects of RPTs on banks' capability, profitability, non-performing loans, liquidity, efficiency, and market value.

The findings of this study theoretically imply that RPTs in banks support both the efficient transaction hypothesis and the conflict of interest hypothesis (Gordon et al. 2004). Further, the presence of a political connection, the political connection index, and the number of politically connected personnel in banks significantly affect banks' capability, profitability, non-performing loans, liquidity, efficiency, and market value through RPTs. The findings also provide practical advice to investors to consider the presence of political connection in banks in their investment decisions. For regulators, this study can inform the Indonesian Accounting Standards Board review the Indonesian Financial Accounting Standard (PSAK - Pernyataan Standar Akuntansi Keuangan) No. 7 , especially in the identification of the relationship and RPTs that has not accommodated the political connection aspect. Lastly, the Indonesian Service Authority can also consult to this study in regulating banks' corporate governance, especially for the composition of politically connected board members.

This study is subject to several caveats. Firstly, although we have strived to use all information available in the media to measure the presence of a political connection, it is still likely that our subjectivity affects the measurement process. Secondly, this study does not consider the macroeconomic condition. The macroeconomic situation, such as interest rate, inflation rate, or changing governmental policies related to the banking industry during the observation period likely affects bank performance. We then suggest that future research consider these factors.

\section{Acknowledgements}

We are very grateful to Faculty of Economics and Business, Satya Wacana Christian University, Diponegoro Street 5260 , Salatiga, 50711, Indonesia, for the support and funding provided for the publication of this article, where the first author was a teaching staff at this institution.

\section{Funding}

This publication was supported by Faculty of Economics and Business, Satya Wacana Christian University, Diponegoro Street 52-60, Salatiga, 50711, Indonesia.

\section{Author contributions}

All authors conceived the study and responsible for design and development of the data analysis. Supatmi wrote the first draft of the article and was responsible for data colletion and analysis. All authors were responsible for data interpretation. All authors have approved the content of the submitted manuscript.

\section{Disclosure statement}

This article has no competing financial, professional, or personal interest from other parties.

\section{References}

Adhikari A, Derashid C, Zhang H (2006) Public policy, political connections, and effective tax rates: Longitudinal evidence from Malaysia. Journal of Accounting and Public Policy 25: 574-595. https://doi.org/10.1016/j.jaccpubpol.2006.07.001

Ang JS, Ding DK, Thong TY (2013) Political connection and firm value. Asian Development Review 30 (2): 131-166. https://doi. org/10.1162/ADEV_a_00018

Annual reports (2019) www.idx.co.id

Bona-Sánchez C, Pérez-Alemán J, Santana-Martín DJ (2014) Politically connected firms and earnings informativeness in the controlling versus minority shareholders context: European evidence. Corporate Governance: An International Review 22 (4): 330-346. https://doi.org/10.1111/corg.12064

Cheung YL, Jing L, Lu T, Rau PR, Stouraitis A (2009) Tunneling and propping up: An analysis of related party transactions by Chinese listed companies. Pacific Basin Finance Journal 17: 372-393. https://doi.org/10.1016/j.pacfin.2008.10.001

Claessens S, Djankov S, Lang LHP (2000) The separation of ownership and control in East Asian corporations. Journal of Financial Economics 58: 81-112. https://doi.org/10.1016/ S0304-405X(00)00067-2

Downs DH, Ooi JTL, Wong WC, Ong SE (2016) Related party transactions and firm value: evidence from property markets in Hong Kong, Malaysia and Singapore. Journal of Real Estate Finance and Economics 52 (4): 408-427. https://doi org/10.1007/s11146-015-9509-0.

Faccio M (2006) Politically connected firms. American Economic Review 96: 369-386. https://doi.org/10.1257/000282806 776157704

Fisman R (2001) Estimating the value of political connections. The American Economic Review 91 (4): 1095-1102. http:// www.jstor.org/stable/2677829

Friedman E, Johnson S, Mitton T (2003) Propping and tunneling. Journal of Comparative Economics 31: $732-750$ http://www. nber.org/papers/w9949

Gordon EA, Henry E (2005) Related party transaction and earnings management: Working paper. Rutgers University http://www.ssrn.com

Gordon EA, Henry E, Palia D (2004) Related party transactions: Associations with corporate governance and firm value. SSRN http://www.ssrn.com

Habib A, Muhammadi AH, Jiang H (2017) Political connections and related party transactions: Evidence from Indonesia. The International Journal of Accounting 52: 45-63. https://doi. org/10.1016/j.intacc.2017.01.004 
Hillman AJ (2005) Politicians on the board of directors: Do connections affect the bottom line? Journal of Management 31: 464-481. https://doi.org/10.1177/0149206304272187

Jensen MC, Meckling WH (1976) Theory of the firm: managerial behavior, agency costs and ownership structure. Journal of Financial Economics 3 (4): 305-360. https://doi. org/10.1016/0304-405X(76)90026-X

Jian M, Wong TJ (2003) Earnings management and tunneling through related party transactions: Evidence from Chinese corporate groups www.cnstock.com

Johnson S, Mitton T (2003) Cronyism and capital controls: Evidence from Malaysia. Journal of Financial Economics 67 (2): 351-382. https://doi.org/10.1016/S0304-405X(02)00255-6

Leuz C, Oberholzer-Gee F (2006) Political relationships, global financing and corporate transparency: Evidence from Indonesia. Journal of Financial Economics 81: 422-439. https:// doi.org/10.1016/j.jineco.2005.06.006

Lin WY, Liu YA, Keng I (2010) Related party transactions, firm performance and control mechanisms: Evidence from Taiwan. International Research Journal of Finance and Economics 35: 82-98 http://www.eurojournals.com/finance.htm

Ling L, Zhou X, Liang Q, Song P, Zeng H (2016) Political connections, overinvestments and firm performance: Evidence from Chinese listed real estate firms. Finance Research Letters 18: 328-333. https://doi.org/10.1016/j.frl.2016.05.009

Liu C, Uchida K, Yang Y (2012) Corporate governance and firm value during the global financial crisis: Evidence from China. International Review of Financial Analysis 21: 70-80. https:// doi.org/10.1016/j.irfa.2011.11.002

Magdalena R, Dananjaya Y (2015) Effect of related parties transactions to the value of enterprises listed on Indonesian Stock Exchange. European Journal of Business and Management 7 (6): 47-57 www.iiste.org

Nekhili M, Cherif M (2011) Related parties transactions and firm's market value: The French case. Review of Accounting and Finance 10 (3): 291-315. https://doi.org/10.1108/ 14757701111155806

Pizzo M (2013) Related party transactions under a contingency perspective. Journal of Management and Governance 17: 309-330. https://doi.org/DOI 10.1007/s10997-011-9178-1

Pozzoli M, Venuti M (2014) Related party transactions and financial performance: is there a correlation? Empirical evidence from Italian Listed Companies. Open Journal of Accounting 03 (01): 28-37. https://doi org/10.4236/ojacct.2014.31004.

Ryngaert M, Thomas SE (2007) Related party transactions: Their origins and wealth effects: Working paper http://ssrn.com/ abstract $=970689$
Sari RC, Fatimah PLR, Djajadikerta HG (2016) Development of tunneling detection model: A new corporate performance improvement. Jurnal Pengurusan 48: 1-20.

Su ZQ, Fung HG, Yau J (2013) Political connections and corporate overinvestment: Evidence from China. International Journal of Accounting and Information Management 21 (4): 285-296. https://doi.org/10.1108/IJAIM-02-2013-0006

Sun P, Hu HW, Hillman AJ (2016) The dark side of board political capital: Enabling blockholder rent appropriation. Academy of Management Journal 59 (5): 1801-1822. https://doi. org/10.5465/amj.2014.0425

Surifah (2013) Family control, board of directors and bank performance in Indonesia. America International Journal of Contemporary Research 3 (6): 115-124.

Tambunan ME, Siregar H, Manurung AH, Priyarsono DS (2017) Related party transactions and firm value in the business groups in the Indonesia stock exchange. Journal of Applied Finance and Banking 7 (3): 1-20. online Scienpress Ltd.

Tao Q, Sun Y, Zhu Y, Yang X (2017) Political connections and government subsidies: Evidence from financially distressed firms in China. Emerging Markets Finance and Trade 53: 1854-1868. https://doi.org/10.1080/1540496X.2017.1332592

Tsai CC, Chang LE, Chang YL (2015) Related party transactions and corporate value. Journal of Economics, Business and Management 3 (10): 924-928. https://doi.org/10.7763/JOEBM.2015.V3.310

Utama CA, Utama S (2014) Corporate governance, size and disclosure of related party transactions, and firm value: Indonesia evidence. International Journal of Disclosure and Governance 11 (4): 341-365. https://doi.org/10.1057/jdg.2013.23

Utama S, Utama CA, Yuniasih R (2010) Related party transactionefficient or abusive: Indonesia evidence. Asia Pacific Journal of Accounting and Finance 1: 77-102.

Villalonga B, Amit R (2006) How do family ownership, management, and control affect firm value? Journal of Financial Economics 80: 385-417. https://doi.org/10.1016/j. jineco.2004.12.005

Wahab EAA, Haron H, Lok CL, Yahya S (2011) Does corporate governance matter? Evidence from related party transactions in Malaysia. Advances in Financial Economics 14: 131-164. https://doi.org/10.1108/S1569-3732(2011)0000014009

Watts R, Zimmerman JL (1986) Positive accounting theory. New York: Prentice-Hall.

Wong RMK, Kim JB, Lo AWY (2015) Are related-party sales value-adding or value-destroying? Evidence from China. Journal of International Financial Management and Accounting 26 (1): 1-38. https://doi.org/10.1111/jifm.12023 
Appendix A. Example of determining index of political connections

\begin{tabular}{|l|l|l|l|l|}
\hline \multicolumn{1}{|c|}{ Company } & $\begin{array}{c}\text { The existence } \\
\text { of a political } \\
\text { connection } \\
\text { (PCDUM) }\end{array}$ & $\begin{array}{c}\text { Number of } \\
\text { board connected } \\
\text { politically } \\
\text { (PCTOT) }\end{array}$ & $\begin{array}{c}\text { Index of } \\
\text { political con- } \\
\text { nections } \\
\text { (PCIDX) }\end{array}$ & Explanation \\
\hline $\begin{array}{l}\text { Bank Negara } \\
\text { Indonesia, Tbk. } \\
\text { (BBNI) }\end{array}$ & There is PC & Two person & Ln16=2.773 & $\begin{array}{l}56.75 \% \text { of the shares are owned by the Indonesian go- } \\
\text { vernment and under the direct control of the Minister of } \\
\text { Finance and the Minister of SOEs. }\end{array}$ \\
\hline $\begin{array}{l}\text { PT Bank MNC } \\
\text { Internasional } \\
\text { Tbk. (BABP) }\end{array}$ & There is PC & Lne Person & $\begin{array}{l}\text { Purnadi Harjono (member of commissioner) affiliated } \\
\text { with the main shareholder, Hary Tanoesoedibjo who is } \\
\text { the leader of Perindo (political party) and member of the } \\
\text { other political party previously. }\end{array}$ \\
\hline $\begin{array}{l}\text { Bank Permata, } \\
\text { Tbk. (BNLI) }\end{array}$ & There is PC & One person & Ln6 $=1.792$ & $\begin{array}{l}\text { Lukita D. Tuwo as Independent Commissioner has served } \\
\text { as Deputy Minister of National Development Planning } \\
\text { and member of the Financial Sector Policy Committee } \\
\text { (KKSK) from 2000-2006. }\end{array}$ \\
\hline
\end{tabular}

